\title{
The Design of a Device for Testing the Tribological Properties of Knee Endopro- stheses
}

Lucie Dobrovolna (0000-0003-1429-5500)' , Matus Varhanik (0000-0001-8108-0070)1, Josef Sedlak (0000-00029819-8259) ${ }^{1}$, Ales Polzer (0000-0001-8124-803X) ${ }^{1}$, Zbynek Studeny (0000-0003-3189-6738) ${ }^{2}$

${ }^{1}$ Department of Machining Technology, Institute of Manufacturing Technology, Faculty of Mechanical Engineering, Brno University of Technology, Technicka 2896/2, Brno 616 69, Czech Republic. E-mail: 193091@vutbr.cz, matus.varhanik@vutbr.cz, sedlak@fme.vutbr.cz,polzer@fme.vutbr.cz

${ }_{2}^{2}$ Department of Mechanical Engineering, Faculty of Military Technology, University of Defence in Brno, Kounicova 65, Brno 602 00, Czech Republic. E-mail: zbynek.studeny@unob.cz

The presented paper deals with the design of a knee simulator that uses pin-on-ball configuration, ie cartilage and CoCrMo head. The translational motion consists of the cartilage and the rotating head when the load of the articulating pair is derived. The simulator meets the predetermined kinematic conditions according to the ISO 14243-3 standard, including dynamic loading. The simulator is able to record the coefficient of friction during the test, which helps to understand the biotribological processes in the knee. The structural part of the simulator is preceded by a research part, in which the existing simulators and tribometers, which helped to create this design, are analyzed. In the experimental part, specific elements (drives, sensors, etc.) are selected that meet the defined boundary conditions, and the method of friction measurement is determined. The paper concludes with an overall evaluation of the proposed knee joint simulator, which will be able to achieve the conditions according to ISO 14243-3 and at the same time record the course of the coefficient of friction between the cartilage surface and the CoCrMo head.

Keywords: biotribological properties, knee simulator, knee kinematics, friction

\section{Introduction}

The largest and most stressed joint in the human body is the knee joint. Knee joint damage is preceded by unilateral movement, disease, obesity or the patient's age. For this reason, it is necessary to pay more attention to the research of biotribological and biomechanical properties in the knee joint. Friction is one of the most important causes of cartilage wear. Its size is affected by lubricants and joint kinematics. In case of its damage, it is replaced by a so-called total endoprosthesis $[1,2,3,4]$.

Up to 25,000 joint replacements are implanted annually in the Czech Republic [5], the endoprosthesis is used in the shoulders, elbows and hips. The endoprosthesis is attached to the bones and replaces the cartilage, with an effort to achieve the original properties of the joint, which is not always possible, because the endoprosthesis still has limited capabilities. Endoprostheses are mainly made of titanium alloys Ti6Al4V, CoCrMo alloy or ceramics [6]. Joint simulators are used for their research, which increases the life of endoprostheses and helps to better understand joints while reducing their failure rate. The demands on experiments are increased in controlled conditions and at the same time their frequency is increased. The specific anatomy of each patient's joint has an effect on its life.

Despite the different development and construction of the so-called large human joints, great progress has been made, for example, in the replacement of hand joints, especially in the last decade. Modern medicine places ever-increasing demands on developers, designers and manufacturers around the world, and nowadays various restorations (shoulder, elbow, ankle joints, wrists, silicone finger joint endoprostheses, etc.) are now being mass-produced from various manufacturers. Unfortunately, even in today's modern age, all manufactured human joint implants are a mere compromise between anatomical and physiological reality, although today the most perfect technological possibilities and economic aspects of production cannot fully replace any natural part of the original human tissue $[7,8,9,10,11,12,13,14]$.

Currently on the market there are many different implants from domestic and foreign manufacturers (Beznoska-Poldi, Walter, DePuy-Johnson \& Johnson, Sulzer Medica, M.I.L., Zimmer, Biomet etc.). According to different sizes (six sizes for total endoprosthesis), design (right, left, anatomical, non-anatomical), method of fixation (cemented, uncemented, hybrid), type of operation (primary, revision), etc., individual implants can be divided into several groups [15]. 
The aim of solving problems is to design a simulator that will satisfy the predetermined conditions, including kinematics while walking capture coefficient of friction.

\section{Knee joint anatomy}

The knee is the most complex joint in the human body. Knee-joint [16] forms the articular connection between the femur and the tibia. The knee joint is a very complex joint which, in addition to flexion and extension, combines other movements (rotation and slip). The main components of the knee are the lower end of the femur, the upper end of the tibia and the patella. These parts of the joint are called femorotibial and patellofemoral [17]. The cup increases the strength of the knee when it is stretched and protects the knee in bending. The articular surfaces are covered with cartilage, which is an extremely slippery, strong and flexible material. Cartilage allows the bones to move and at the same time acts as a shock absorber during load transfer $[1,2,3,4,17]$.

There are primary and secondary stabilizers in the knee. Primary stabilization is achieved by the knee ligaments.

Ligaments are fibrous tissue that provides joint support. Cross ligaments are the primary stabilizers of the knee joint. The lateral ligaments ensure lateral movement. The meniscus ligaments fix the two menisci with each other [1].

There are four bursae in the knee, which are cavities filled with synovial fluid that serve to facilitate the movement of tendons and skin through the joint and reduce friction $[1,18]$.

The main movement of the joint is flexion and extension. The knee axis itself is able to move in 5 directions by means of rolling and sliding movements (flexion and extension are the same movements in reverse order) [1].

The basic movements when walking are the initial rotation of $5^{\circ}$, the rolling movement of $10^{\circ}$ to $20^{\circ}$, the sliding movement of $20^{\circ}$ to $140^{\circ}$ and the final rotation. Thanks to the lateral ligaments on the back of the joint, the knee is able to unlock and lock. Full extension occurs during unlocking and flexion during locking [1].

\section{Existing simulators}

In the next chapter, simulators will be analyzed, which served as inspiration in creating the problem. The "Ball on Disc" configuration seems to be a suitable design solution for the simulator for the purpose of testing the tribology of the knee joint [19].

\subsection{Bioreactor simulator}

The simulator is created in a pin-on-ball configuration, where the head acts on the articulating cartilage.
The rotation of the head and the pin is formed directly by the stepper motor, which is connected to the moving screw and controlled by stepper motors. It is capable of forces from 0 to $250 \mathrm{~N}$ and speeds of 20 $\mathrm{mm} . \mathrm{s}^{-1}$ in all axes. Its maximum force of $250 \mathrm{~N}$ is taken as the initial load value of this work. The test is performed under conditions of $37^{\circ} \mathrm{C}$ and $5 \% \mathrm{CO}_{2}$ [20].

Fig. 1 shows two stepper motors providing linear motion (1 and 2). The pressure is caused by the linear actuator (3). The samples are placed in the sample holder (4). Fluid channels $(5,6,7)$ are provided throughout the structure, providing nutrition. Patterns covered by a glass cover (8) [20].

A load cell with optional settings is located under the sample holder to allow adjustment of displacement control as well as load.

The device is equipped with a cell inoculation system, which is mounted directly on the sample holder. It is formed using biocompatible pear-shaped materials to minimize fluid flow [20].

The Bioreactor simulator is also created in a concept with four stations.

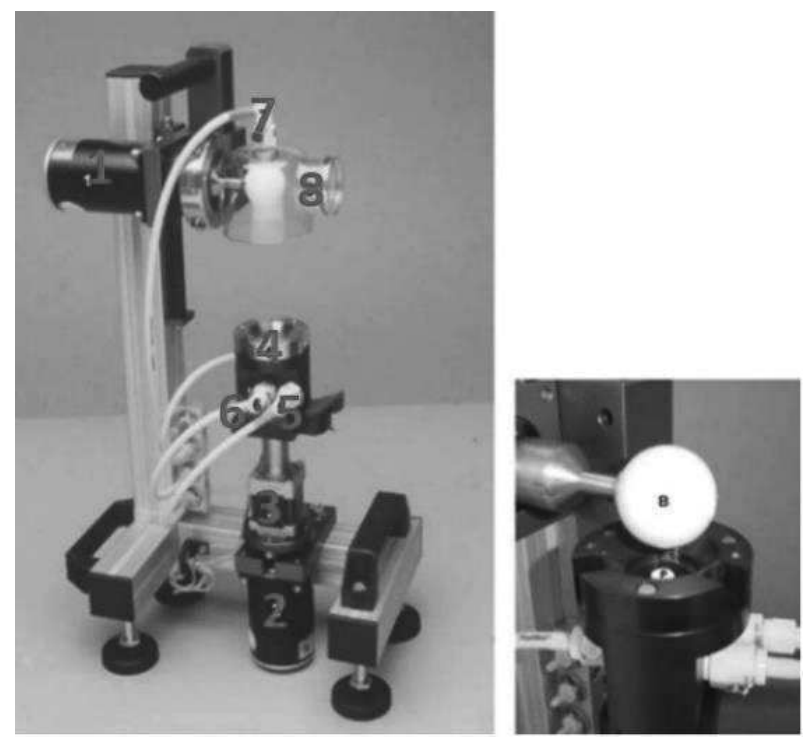

Fig. 1 Bioreactor simulator [20]

\subsection{CNC-POD simulator}

The simulator uses a pin-on-disk configuration. It is designed for wear testing. The simulator comprises 6 stations, each comprising a ball or a pin which is mounted on a holder, the disc on the opposite side being a component which is mounted in the holder. It is possible to perform 6 different experiments simultaneously on the simulator. Each station contains a sample holder, holder bases and containers [21].

On the CNC-POD, it is possible to create a oneway reciprocating or rectangular movement (ensures travel), in which there are two NEMA 24 stepper motors in the XY direction (controlled independently). From the motors, the rotary motion is converted to 
linear by means of a moving screw. The guide is formed by four linear bearings, which are placed on rails. The minimum step of the screw is a displacement of $0.001 \mathrm{~mm}$ [21].

The load is created in the structure by means of linear actuators. The actuators are mounted on an

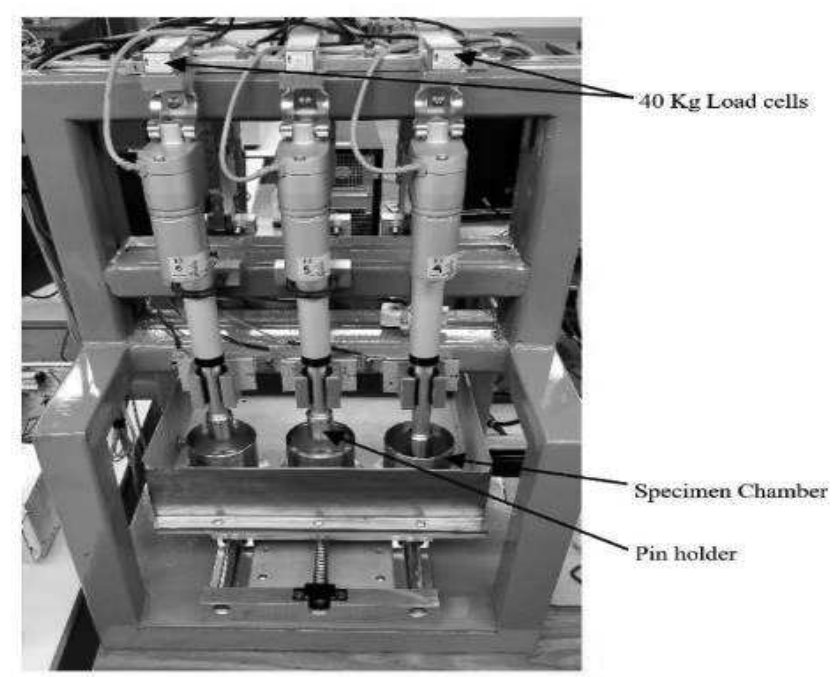

adapter that connects the mounting bracket to the linear bearing. The maximum possible load is $40 \mathrm{~kg}$. Each actuator has an integrated rail that serves as a stroke guide to prevent unwanted movement during loading. Each station contains a force sensor that can be used to determine the friction force. The CNCPOD simulator is shown in Fig. 2 [21].

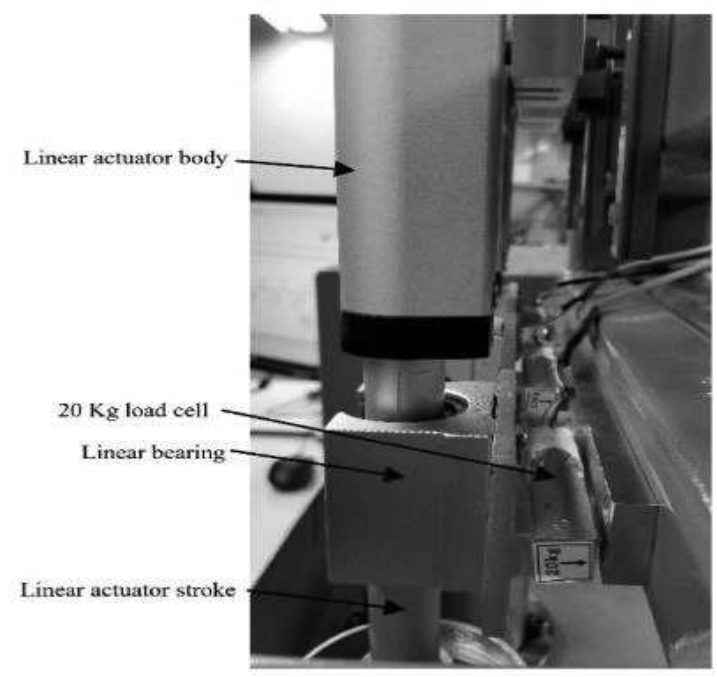

Fig. 2CNC-POD simulator [21]

\subsection{Industrial robot simulator}

The simulator is used to evaluate total compensations during dynamic movement. It consists of an industrial robot that performs a movement, a six-axis force transducer mounted on a support with a tibial component. The end effector is equipped with a femoral component. The robot moves according to the supplied model of the right limb. The model is a musculoskeletal multibody, including bones, ligaments, muscles and an implanted total knee arthroplasty. The construction of the simulator can be seen in Fig. 3. The simulation includes 2 control loops. The motion sequence and reaction forces with moments are transmitted to the robot, thus closing the first loop. Rotations and modified relative displacements are transferred back to the musculoskeletal model, closing the second loop. Both control loops are defined by processing the spatial directions of movement [22].

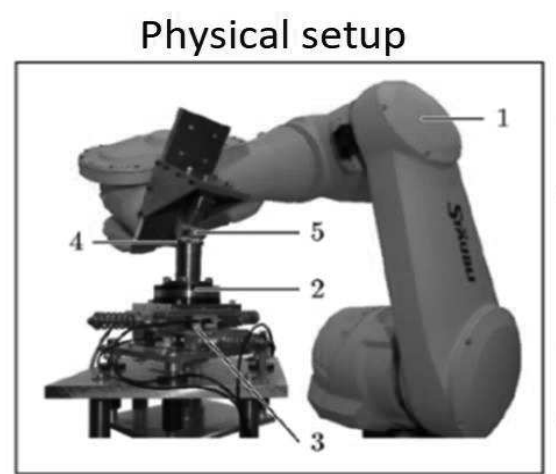

Industrial robot with total knee endoprosthesis

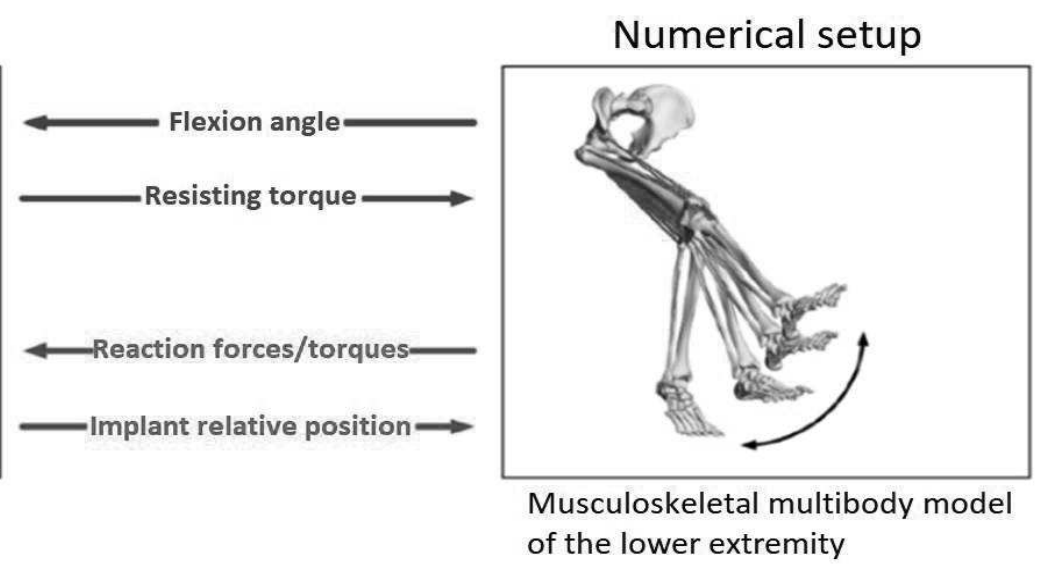

Fig. 3 Industrial robot simulator [22]

\section{Experimental part - constructional solu- tion}

The default values for this experiment are based on
ISO 14243-3. Based on the analysis of joint movement, the load, head rotation and cartilage displacement are selected. The last movement of the cartilage rotation will not be considered, as it will not change the resulting value too much [22]. 


\subsection{Anterior-posterial movement}

Anterior-posterial movement is a linear movement that is formed by cartilage. The initial values for this work are taken from the ISO 14243-3 standard, the plot of which is shown in Fig. 4. The speed was determined by deriving the displacement in Fig. 5 [23].

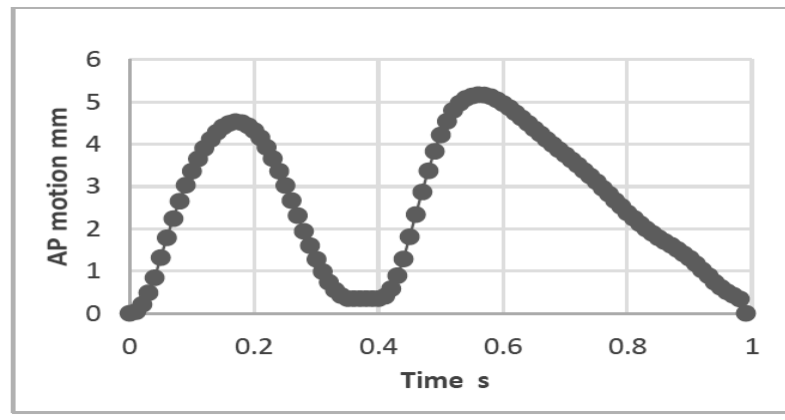

Fig. 4 Anterior-posterial movement [23]

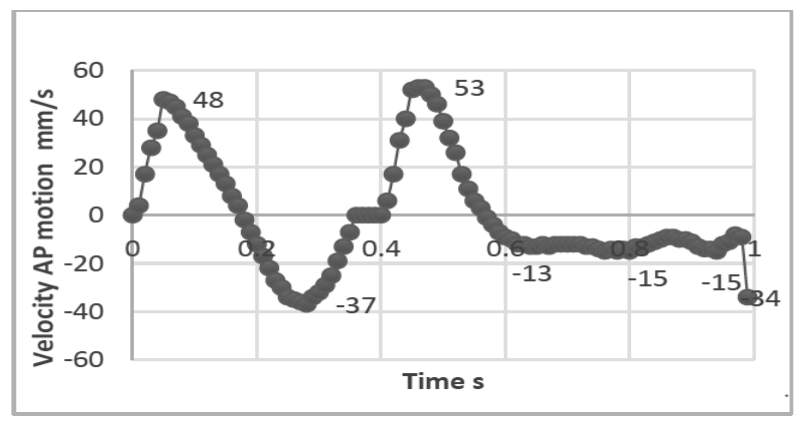

Fig. 5 The speed of anterior-posterial movement [23]

Based on the graphical dependences from Fig. 4 and Fig. 5, initial values were obtained for the selection of the drive that will perform the anterioposterial movement.

\section{Construction of Anterio-posterial (A/P) movement}

The LEYH25RS2A-50B F-SA1 drive from SMC s.r.o. was chosen for the design with the following technical data:

- power $100 \mathrm{~W}$,

- $\quad$ stroke $50 \mathrm{~mm}$,

- variant with brake,

- $\quad$ standard cable $2 \mathrm{~m}$ long

- force $122 \mathrm{~N}$,

- $\quad$ speed from 18 to $500 \mathrm{~mm} . \mathrm{s}^{-1}$,

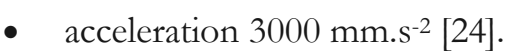

The drive is controlled by the LESCA1 driver (100 $\mathrm{V}$ to $120 \mathrm{~V}$ ).

To ensure the frictionless movement of the cartilage, it was necessary to choose a suitable feed design. The most suitable solution is an air bearing, due to the fact that air is blown between the bearing and the shaft, thanks to which it is able to work without resistance. The bearing is housed in a house that is de- signed for this construction. The house has three holes on the side, two are used to secure the bearing in the house with epoxy resin and the third hole is used to supply air by $0.41 \mathrm{MPa}$. The disadvantage of this concept is the need to provide air and possible distortion of the measurement caused by the resistance of the hoses. To further secure the bearing, O-rings are used, for which grooves are located around the circumference of the bearing. The house has a milled hole on the upper side, in which a bowl with cartilage is pressed on, see Fig. 6. The construction of the connection between the house and the actuator is shown in Fig. 7 [23].

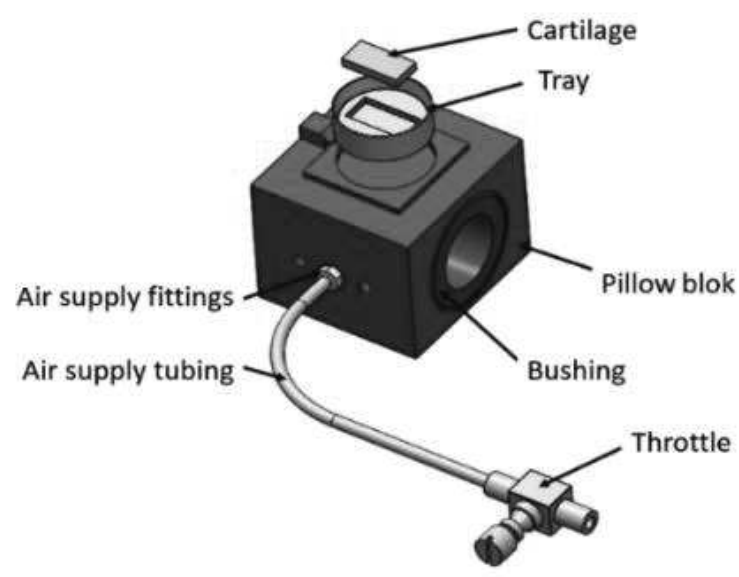

Fig. 6 Air bearing assembly

A bearing of $25 \mathrm{~mm}$ can be loaded with a maximum radial force of $226.3 \mathrm{~N}$, therefore it is necessary to reduce the predetermined force, based on the cell [20] from $250 \mathrm{~N}$ to $200 \mathrm{~N}$. The radial stiffness of the bearing is set at $34 \mathrm{~N}$.

Friction measurement is provided by a BURSTER s.r.o. strain gauge. $8431-5100$, which is bolted to the bearing and bearing housing by means of a reducer. The strain gauge is capable of measuring force up to $100 \mathrm{~N}$ with an inaccuracy of $\pm 0.0004 \mathrm{~N}$. The acceleration is controlled by means of an accelerometer A / 124 / E glued to the house, the error rate of which is $\left.0.1 \mathrm{mV} \cdot \mathrm{m}^{-1} \cdot \mathrm{s}^{-2}\right)$. The accelerometer is able to measure the maximum acceleration up to $49.033 \mathrm{~m} . \mathrm{s}^{-2}$ [23].

Suitable materials to produce the shaft are stainless steel, anodized aluminium, or nickel-plated steel. It is necessary to ensure a tolerance of $\mathrm{g} 6$ on the shaft.

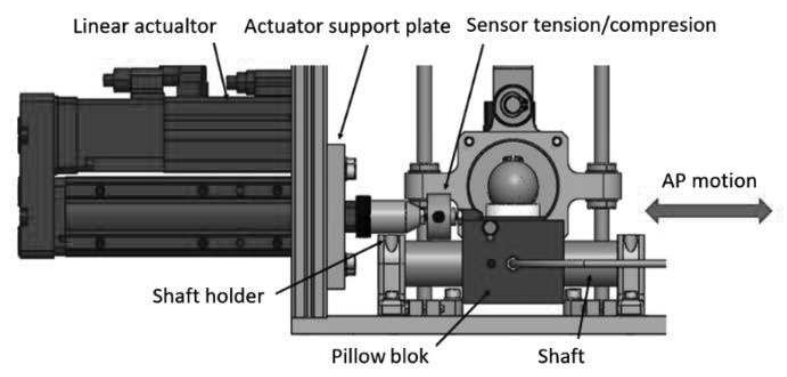

Fig. 7 The design of $A / P$ motion [23] 


\subsection{Head load}

To simplify the construction, the head was chosen, while to further shift the work, it is possible to incorporate the endoprosthesis itself into the structure and to increase the load to $2600 \mathrm{~N}$, which is based on the ISO 14243-3 standard. The graphical dependence of the endoprosthesis is shown on Fig. 8.

- diameter of the head object $28 \mathrm{~mm}$,

- force $250 \mathrm{~N}$,

- endoprosthesis loading $2600 \mathrm{~N}$.

The considered feed is in the order of hundredths, so it is not necessary to verify the maximum speeds and accelerations [23].

At the considered maximum load of the endoprosthesis of $2600 \mathrm{~N}$ and the load of the head of $250 \mathrm{~N}$, the conversion to dynamic force was proved. The illustration is located in graphical dependence on Fig. 9.

Where: $\mathrm{k}[-]$ - coefficient,

$\mathrm{F}_{\mathrm{emax}}[\mathrm{N}]$ - maximum strength of the endoprosthesis,

$\mathrm{F}_{\text {hmax }}[\mathrm{N}]$ - maximum strength of the head,

$\mathrm{F}_{\mathrm{h}}[\mathrm{N}]$ - head force,

$F_{e}[N]$ - strength of the endoprosthesis [23].

$$
k=\frac{F_{\text {emax }}}{F_{\text {hmax }}}=10.4
$$

Example of calculation for the value of the head force $F_{h}$ for time $t=0.25 \mathrm{~s}$

$$
F_{h}=\frac{F_{e}}{k}=\frac{838.2}{10.4}=80.6 \mathrm{~N}
$$

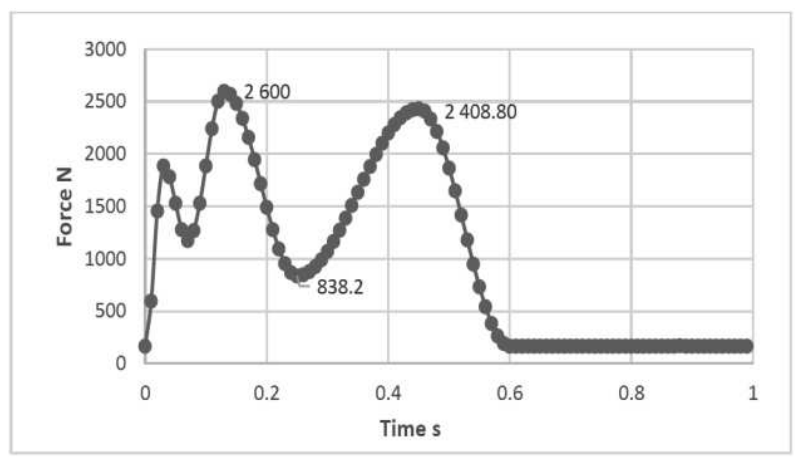

Fig. $\boldsymbol{8}$ The load of endoprosthesis [23]

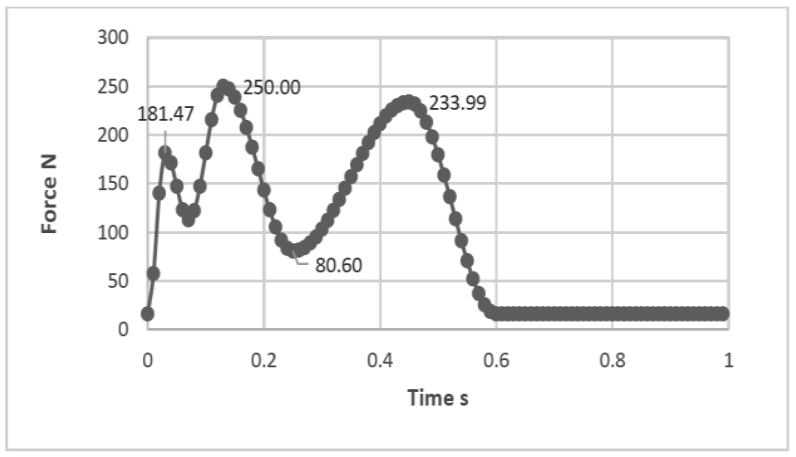

Fig. 9 Head load [23]

\section{Construction of electric drive load}

The electric screw drive forms the vertical movement of the whole system, which is the head with the servomotor. The load reaches a maximum of 200 $\mathrm{N}$ and is measured between the piston rod and the drive hinge, see Fig. 10.

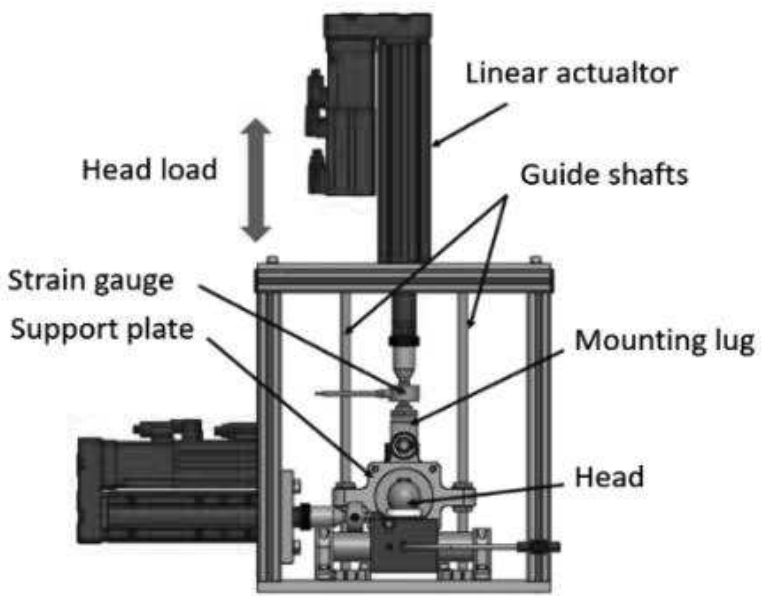

Fig. 10 The electric drive load [23]

The drive under the designation LEY H25 R S2 C - 100 BM - S 2 A1 was selected from SMC s.r.o. The load will be verified by means of a sensor located in the structure, which changes dynamically according to the graphical dependence on Fig. 9 in subchapter 4.2 [23]. The drive with the following technical data was chosen for the construction:

- power $100 \mathrm{~W}$,

- $\quad$ stroke $100 \mathrm{~mm}$,

- variant with brake,

- $\quad$ standard cable $2 \mathrm{~m}$ long,

- force $238 \mathrm{~N}$,

- $\quad$ speed from 9 to $250 \mathrm{~mm} . \mathrm{s}^{-1}$,

- vertical working load $16 \mathrm{~kg}$,

- $\quad$ acceleration 3000 mm.s ${ }^{-2}$ [24].

Part of the motor is driver LECSA1 $100 \mathrm{~V}$ to 120 $\mathrm{V}$, which is from the same company.

The load consists of an actuator, which is attached to the support plates, between which a strain gauge sensor is screwed, which works to control the load. A suspension eye with reducers is used to attach the plate to the actuator. To absorb the radial load, a radial double-row angular contact ball bearing 3205 ATN9/C3 is pressed into the plate. The whole diagram is shown on Fig. 11 [23].

The actuator is attached to the upper aluminum plate and its movement is guided by means of guide rods with a diameter of $8 \mathrm{~mm}$, on which the sliding bushes UB-08AWW from the company HIWIN s.r.o. Retaining rings are used to fasten them. The ends of the rods are secured with rod sleeves, see Fig. 12 [23]. 


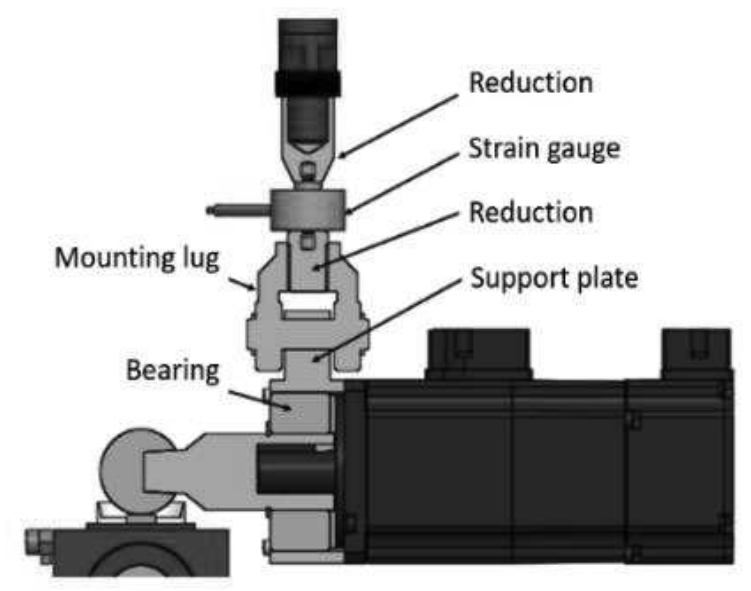

Fig. 11 The design of drive connecting [7]

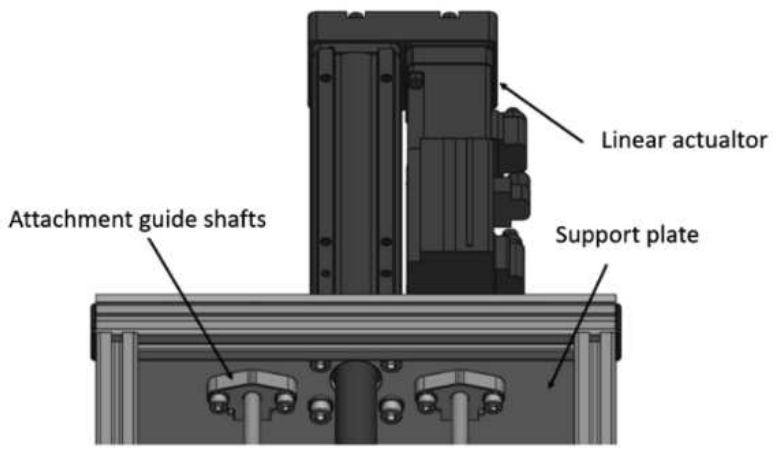

Fig. 12 The connection of drive to construction [7]

\subsection{Head rotation}

The head moves in the range from $0^{\circ}$ to $60^{\circ}$, see Fig. 13, the values based on ISO 14243-3. The angular velocity is obtained by derivation, see Fig. 14. Acceleration is obtained by derivation of velocity.

$$
\begin{gathered}
F_{t}=N \cdot f \\
F_{t}=200 \cdot 0.1621=32.42 \mathrm{~N} \\
M_{k}=r \cdot F_{t} \\
M_{k}=0.014 \cdot 32.42=0.45 \mathrm{Nm}
\end{gathered}
$$

The resulting torque, which is one of the default values for motor selection, is $0.45 \mathrm{Nm}$. The assumed friction force is $32.42 \mathrm{~N}$, in the case of using a head with a diameter of $28 \mathrm{~mm}$ [23].

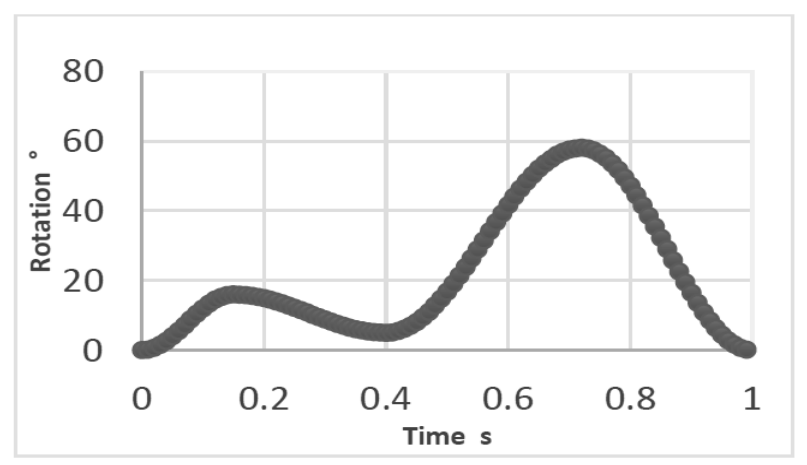

Fig. 13 Flexion/extension [23]

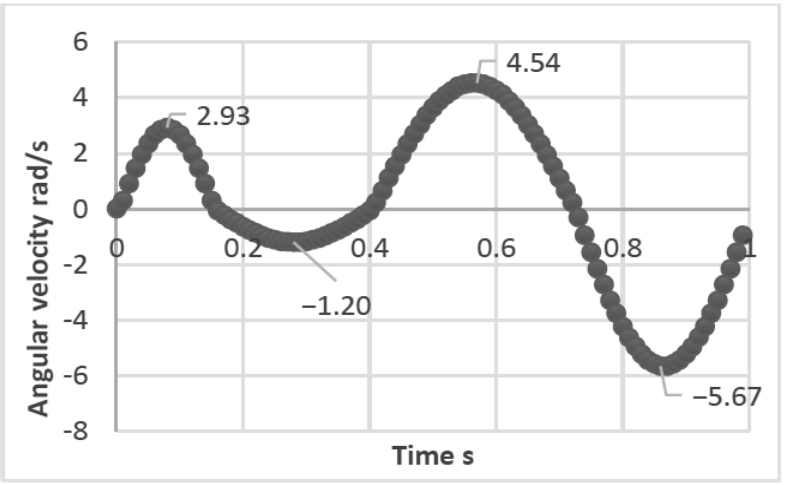

Fig. 14 Head angular velocity [23]

\section{Servomotor - ensuring rotary movement}

To ensure rotational motion was chosen servomotor. The default values for the motor selection are taken from the previous solution, on the basis of which the servomotor from HIWIN s.r.o. was chosen FRLS $100 \mathrm{~W}$. A variant with a tongue (tight tongue DIN 6885 A $5 \times 5 \times 25$ ) on a shaft with a diameter of $14 \mathrm{~mm}$ and a length of $30 \mathrm{~mm}$ [23] was chosen for torque transmission. A servomotor with the following technical data was chosen for the construction:

- rated power $200 \mathrm{~W}$,

- maximum speed $4500 \mathrm{rpm}$,

- $\quad$ rated speed $3000 \mathrm{rpm}$,

- maximum torque $1.92 \mathrm{Nm}$,

- rated torque $0.64 \mathrm{Nm}$ [25].

The HIWIN D2T - 0123 frequency converter, which is specially designed for HIWIN motors, was added to speed control. The motor connection for the head rotation is shown on Fig. 15.

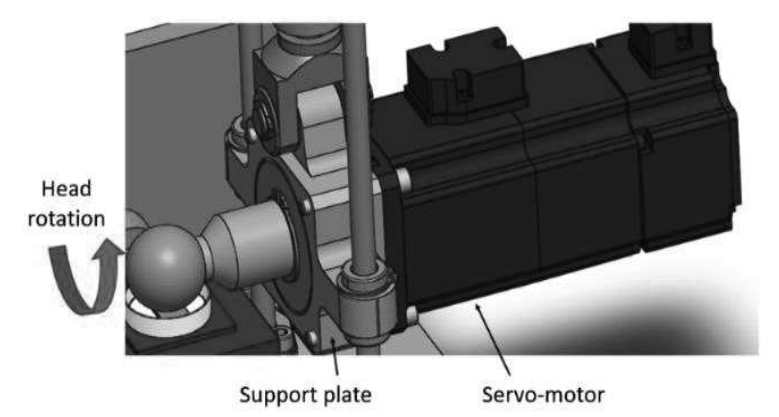

Fig. 15 The connection of servomotor for head rotation [23]

\section{Construction of the rotation head}

The rotation is transmitted by means of the already mentioned tongue to the shaft, which has a adapted end for attaching the head. The servomotor is attached to the aluminum plate with screws. A bearing for removing the radial load is pressed into the plate. There is a slip ring between the bearing and the servomotor, which defines the bearing relative to the servomotor and prevents abrasion, see Fig. 16 [23]. 


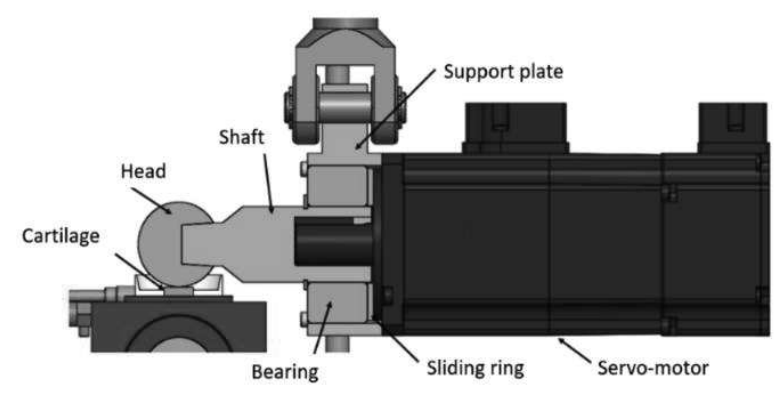

Fig. 16 The construction model of head rotation

\subsection{Simulator design}

The frame consists of aluminum profiles of profile series 5 with a size of $20 \times 20 \mathrm{~mm}$ from the company Alváris Profil Systems s.r.o. All connected elements are connected to the structure by grooved nuts by means of a groove in the profile. The ends of the profiles are covered with caps. The board itself has drilled holes and milled parts for mounting the entire assembly, see Fig. 17 [23].

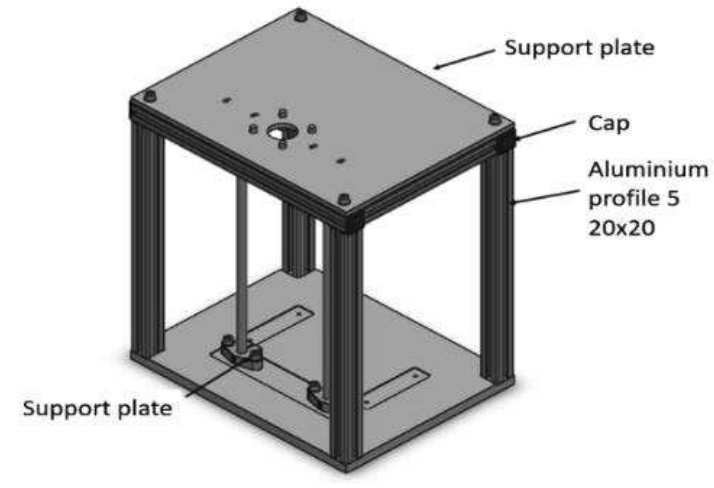

Fig. 17 The frame simulator [23]

\subsection{Test serum}

The standardized serum is composed of bovine serum diluted with deionized water to have a protein mass concentration of $20 \mathrm{~g}^{-1} \mathrm{l}^{-1}$. The serum is filtered through a $2 \mu \mathrm{m}$ filter. Store in the freezer until tested to prevent microbial contamination or add an antimicrobial number [23].

\section{Conclusions}

The aim of the problem was to design a simulator that will record the coefficient of friction between the CoCrMo head and the cartilage surface during the movement. According to the ISO 14243-3 standard, the proposed simulator will achieve predetermined conditions:

- anterio-posterior movement from 0 to 5.2 $\mathrm{mm}$,

- head rotation from $0^{\circ}$ to $60^{\circ}$,

- head load from 0 to $200 \mathrm{~N}$.

- considered coefficient of friction up to 0.1621 [23].
A coefficient of friction of 0.05 was chosen for the measurement, which is based on the performed search. From the experimental measurement, a coefficient of friction of 0.1621 was found, the magnitude of which is significantly higher than the value from the search, because it was measured under degraded conditions without lubricant. The parameters are met by a suitable choice of components for the construction of the simulator [26, 27].

Anterio-posterior movement is created by means of an electric screw drive, which is capable of dynamic changes. The drive moves with an air bearing lying on the shaft. The air bearing has an attached cup with cartilage and synovial fluid. It is necessary to supply air to the bearing with a pressure of $0.41 \mathrm{MPa}$ using a hose and valves. With the help of air, the bearing is able to work without friction. There is an air gap between the bearing and the shaft. A probable problem in determining the coefficient of friction is the inaccuracy caused by the resistance of the hose. The drive is capable of speeds from 18 to $500 \mathrm{~mm} \cdot \mathrm{s}^{-2}$ and accelerations of up to $3000 \mathrm{~mm} \cdot \mathrm{s}^{-2}$.

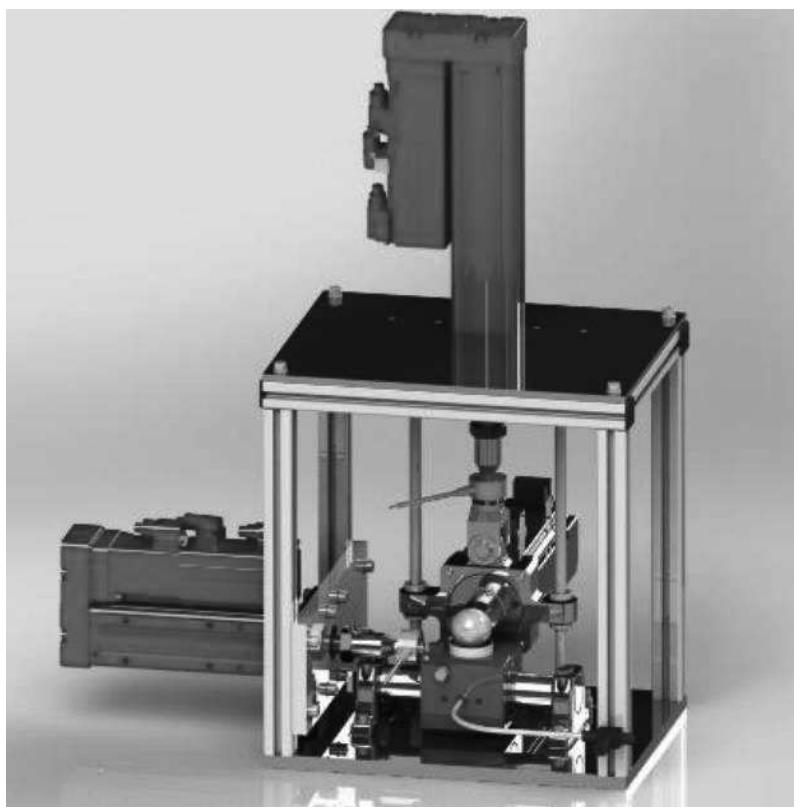

Fig. 18 The entire simulator design [23]

The rotation of the head is formed by a servomotor, which is again able to meet the requirements for large dynamic changes. The servomotor rotates the head and meets predetermined conditions. The shaft is mounted in bearings to prevent undesired forces. The servomotor is able to reach a speed of 5.67 rad.s 1 and withstands a torque of $0.14 \mathrm{Nm}$.

The load on the head is caused by an electric screw drive, which is guided by means of two guide rods and compact bushings. The stroke length is $100 \mathrm{~mm}$ and it is able to exert a force of up to $238 \mathrm{~N}$.

The coefficient of friction is measured by means of 
a strain gauge, which is connected between the bearing housing and an electric screw drive with an accuracy of $\pm 0.0004 \mathrm{~N}$. The default value of the coefficient of friction is 0.1621 and a force of $200 \mathrm{~N}$. At these input values the resulting friction force is $32.42 \mathrm{~N}$ [23].

The design of entire simulator rendered by CAD program shows the Fig. 18 [23].

\section{Acknowledgement}

This research work was supported by the Brno University of Technology, Faculty of Mechanical Engineering, Specific research 2020, with the grant "Testing of tribological properties between heterogeneous materials used in medicine", FCH/FSI-J-20-6276.

The paper has been prepared thanks to the support of the project The Development of Technologies, Design of Firearms, Ammunition, Instrumentation, Engineering of Materials and Military Infrastructure "VÝZBROJ (DZRO K201)".

\section{References}

[1] ČIHÁK, R. Anatomie I. 1. vydání. Praha: Grada Publishing, spol. s.r.o., 2001. 497 s. ISBN 807169-970-5.

[2] SEDLÁK, J., SLANÝ, M., FIALA, Z., JAROŠ, A. Production Method of Implant Prototype of Knee-Joint Femoral Component. Manufacturing Technology, 2015, Vol. 15, No. 2, p. 195-204. ISSN 1213-2489.

[3] SEDLÁK, J.; SLANÝ, M.; FIALA, Z.; JAROŠ, A.; BLAŽKOVÁ, V. Testing of Implant Prototype of Femoral Component Using Hydraulic Machine ZD40. Manufacturing Technology, 2015, Vol. 2015, No. 3, p. 416-423. ISSN 1213- 2489.

[4] SEDLÁK, J., CHLADIL, J., SLANÝ, M., KOUŘIL, K. Introduction to Processing of CT Clinical Metadata of Disabled Part of Patient Knee Joint. Manufacturing Technology, 2014, Vol. 14, No. 4, p. 611-618. ISSN 1213- 2489.

[5] ULTRAVYSOKOMOLEKULÁRNÍ POLYETHYLEN PRO KLOUBNÍ NÁHRADY SE ZVÝŠENOU ŽIVOTNOSTÍ. Chem. Listy. [online]. Praha: Ústav makromolekulární chemie AV ČR, 2013, 6. 9. 2013, 2013(107), 783-790 [cit. 2019-0510]. Dostupné z: http://www.chemickelisty.cz/docs/full/2013_10_783-790.pdf

[6] NOVÁ, K., NOVÁK, P., KNAISLOVÁ, A., DVORSKÝ, D., ZÝKA, J. Microstructure of New Cobalt Alloy for Medical Use. Manufacturing Technology, 2016, Vol. 16, No. 5, p. 1091 1095. ISSN 1213-2489.
[7] BEZNOSKA, S., ČECH, O., LÖBL, K. Umélé nábrady lidských kloubư. Biomechanické, materiálové a technologické aspekty. SNTL, Praha, 1987.

[8] ČECH, O., PAVLANSKÝ, R. Aloplastika kyčelního kloubu. Avicenum, Praha, 1979.

[9] ČECH, O. et al. Aloplastika. Avicenum, Praha, 1983a.

[10] ČECH, O. et al. Aloplastika kyčelního kloubu. Avicenum, Praha, 1983b.

[11] HUGGLER, A., H., SCHREIBER, A. Alloarthroplastik des Huftgelenkes. Georg Thieme, Stuttgart, 1978.

[12] CHARNLEY, J. Low Friction Arthroplasty. Springer Verlag, New York, 1979.

[13] PETRTÝL, M., ONDROUCH, A., MILBAUER, M. Experimentálni biomechanika pernéfáze lidskébo skeletu. Academia, Praha, 1985.

[14] STEHLÍK, J., TVRDEK, M., BARTONÍČEK, J. The technique of the osteosynthesis in the replantation of the upper limb. Acta. Chir. plast., 34, 1992, 241-248.

[15] Totálni nábrady lidských kloubư. online. [2020-1109]. Dostupné z: http://ucebnice.euromise.cz/index.php? conn $=0 \&$ section $=$ biomech\&node $=$ node 33

[16] Centrum Prof. ČECHA s.r.o. Česká republika. Anatomie kolenního kloubu. [online]. Leden 2007 [2020-11-09]. Dostupné z: http://www.ortopedie.cz/web/webok.html

[17] ABULHASAN, J. F., GREY, M. J. Anatomy and Physiology of Knee Stability. Journal of Functional Morphology and Kinesiology. 2017, Vol. 17, 2(4), 34. Available in: doi:10.3390/jfmk2040034

[18] MEYLER, D. Z. Knee Anatomy. ARTHRITISbealth. [online]. VERITAS-health, 2018 [see 2020-06-13]. Available in: https://www.arthritis-health.com/types/joint-anatomy/knee-anatomy

[19] LICEK, R. Evaluation of Tribological Properties by Using Different Process Fluid by Test Ball on Disc. Manufacturing Technology, 2017, Vol. 17, No. 2, p. 217-223. ISSN 12132489.

[20] WIMMER, M. A., GRAD, S., KAUP, T., HÄNNI, M., SCHNEIDER, E., GOGOLEWSKI, S., ALINI, M. Tribology $A p$ proach to the Engineering and Study of Articular Cartilage. Tissue Engineering. [online]. 2004, 10 (910), p. 1436-1445 [see 2019-05-13]. DOI: 
10.1089/ten.2004.10.1436. ISSN 1076-3279. Available in: https://www.liebertpub.com/doi/10.1089/ten.2004.10.1436

[21] Cortes, V., Rodriguez Betancourth, C.A., Ortega, J.A., Huq, H. Multidirectional Pin-on-Disk Testing Device to Evaluate the Cross-shear Effect on the Wear of Biocompatible Materials. Instruments 2019, 3, 35.

[22] Kebbach, M., Grawe, R., Geier, A. et al. Effect of surgical parameters on the biomechanical behaviour of bicondylar total knee endoprostheses - A robot-assisted test method based on a musculoskeletal model. Sci Rep 9, 14504 (2019). Available in: https://doi.org/10.1038/s41598-019-50399-3

[23] DOBROVOLNÁ, Lucie. Návrh simulátoru pro analyzu tření v kolennim kloubu. [Online]. Brno 2020 Dostupné z: https://www.vutbr.cz/studenti/zavprace/detail/124358. Bakalářská práce. Vysoké učení technické v Brně, Fakulta strojního inženýrství, Ústav strojírenské technologie. 79 s. 5 prríloh. Vedoucí práce doc. Ing. Josef Sedlák, Ph.D.
[24] LEY. Copyright (C) 2020 SMC Corporation. [online]. [see 2020-11-09]. Available in: https://www.smc.eu/cs-cz/produkty-apodpora/ley 134002 nav

[25] HIWIN S.R.O. Servo motor FRLS 100W. [Online]. [cit. 2020-11-09]. Dostupné z: https://www.hiwin.cz/cz/produkty/motory/servo-motory/117_servo-motor-frls$100 \mathrm{w}$

[26] VASINA, M., PÖSCHL, M., ZADRAPA, P. (2021). Influence of Rubber Composition on Mechanical Properties. In: Manufacturing Technology, Vol. 21, No. 2, pp. 260-268. ISSN 12132489.

[27] LAI, H., HUAICHAO W., BENG, Y.K., NING, D., LI, S. (2019) Study on the Layering of the Main Shaft of the Friction and Wear Testing Machine for Slipper Pair Based on CFRP. In: Manufacturing Technology, Vol. 19, No. 2, pp. 261-266. ISSN 1213-2489. 